\title{
Genetic causes of optic nerve hypoplasia
}

\author{
Chun-An Chen, ${ }^{1,2}$ Jiani Yin, ${ }^{1,2}$ Richard Alan Lewis, ${ }^{1,3}$ Christian P Schaaf ${ }^{1,2}$
}

'Department of Molecular and Human Genetics, Baylor College of Medicine, Houston, Texas, USA

${ }^{2} J a n$ and Dan Duncan Neurological Research Institute, Texas Children's Hospital, Houston, Texas, USA ${ }^{3}$ Department of Ophthalmology, Baylor College of Medicine, Houston, Texas, USA

\section{Correspondence to} Dr Christian P Schaaf, Department of Molecular and Human Genetics, Jan and Dan Duncan Neurological Research Institute at Texas Children's Hospital, Baylor College of Medicine, 1250 Moursund Street, Suite 1325, Houston 77030, Texas, USA; schaaf@ bcm.edu

Received 2 March 2017 Accepted 5 April 2017 Published Online First 29 April 2017
CrossMark

To cite: Chen C-A, Yin J, Lewis RA, et al. J Med Genet 2017;54:441-449.

\section{ABSTRACT}

Optic nerve hypoplasia (ONH) is the most common congenital optic nerve anomaly and a leading cause of blindness in the USA. Although most cases of $\mathrm{ONH}$ occur as isolated cases within their respective families, the advancement in molecular diagnostic technology has made us realise that a substantial fraction of cases has identifiable genetic causes, typically de novo mutations. An increasing number of genes has been reported, mutations of which can cause $\mathrm{ONH}$. Many of the genes involved serve as transcription factors, participating in an intricate multistep process critical to eye development and neurogenesis in the neural retina. This review will discuss the respective genes and mutations, human phenotypes, and animal models that have been created to gain a deeper understanding of the disorders. The identification of the underlying gene and mutation provides an important step in diagnosis, medical care and counselling for the affected individuals and their families. We envision that future research will lead to further disease gene identification, but will also teach us about gene-gene and gene-environment interactions relevant to optic nerve development. How much of the functional impairment of the various forms of $\mathrm{ONH}$ is a reflection of altered morphogenesis versus neuronal homeostasis will determine the prospect of therapeutic intervention, with the ultimate goal of improving the quality of life of the individuals affected with $\mathrm{ONH}$.

\section{INTRODUCTION}

The optic nerve, which is composed of retinal ganglion cell axons and supporting glial cells, transmits visual information from the retina to the brain. Optic nerve hypoplasia $(\mathrm{ONH})$ is a non-progressive congenital abnormality characterised by underdevelopment of the optic nerve. Typically, the anomalous optic nerve head appears pale and small, with a pale or pigmented peripapillary halo or doubleringed sign that is visible with ophthalmoscopy. ONH typically occurs bilaterally (80\% of all cases). The severity of visual impairment varies between cases. Some eyes with ONH have no light perception, while others have acceptable levels of functional vision. Severe bilateral $\mathrm{ONH}$ can be diagnosed within the first few months of life. Affected patients typically manifest early-onset sensory nystagmus (involuntary, rapid eye movements), followed by strabismus (inability to align the eyes simultaneously) often related to the visual impairment due to defective communication between eye and brain. Individuals with unilateral $\mathrm{ONH}$ are often diagnosed at an older age, compared with those with bilateral $\mathrm{ONH}$, due to preserved vision in the one normal eye.

The first recorded case of ONH was documented in 1884 in a small child by Magnus. ${ }^{1}$ Magnus noticed a small, pale optic nerve in a boy with nystagmus and a high degree of amblyopia. However, some researchers considered Briere's report to be the first case in $1877 .^{2} \mathrm{He}$ described a 7 -year-old girl who was born blind, with no optic disc, but normal choroid and central retinal vessels. Some commentators have suggested, however, that the presence of retinal vessels must imply an entrance and exit for them, and thus, given the instrumentation of the period, the disc(s) may have been missed. The first schematic illustration of optic disc appearance of $\mathrm{ONH}$ was done by Schwarz in 1915 . $^{3}$ To date, $\mathrm{ONH}$ is the second leading cause of blindness and is the most common congenital optic nerve anomaly in the USA. ${ }^{4}$ The reported prevalences of $\mathrm{ONH}$ range from 2 to 17.3 per $100000,{ }^{5}$ with a considerable rise in prevalence starting in the 1980s. The cause of this increase remains disputed; however, it may be due to heightened physician awareness and improved observation and thus diagnosis of the disorder. Given that most $\mathrm{ONH}$ cases are isolated within their respective families, research into the causal factors of $\mathrm{ONH}$ has focused on environmental effects. Many environmental risk factors for $\mathrm{ONH}$ have been reported, including maternal alcohol abuse during pregnancy, young maternal age, primiparity, maternal use of recreational drugs, anticonvulsants or antidepressants. ${ }^{6}$ However, familial cases of $\mathrm{ONH}$ also exist, ${ }^{7} 8$ suggesting genetic aetiologies. With the recent advancement in molecular diagnostic technology, mutations in an increasing number of genes have been reported to cause ONH.

Although rare, the description of $\mathrm{ONH}$ may sometimes be confused with optic atrophy, ${ }^{69}$ especially when serial examinations have not been done, and the examiner cannot appreciate whether there has been a progression or degeneration over time. Optic atrophy is a condition in which the optic nerve tissues had developed normally and either are damaged and/or degenerate secondarily.

Although ONH can occur as an isolated finding, it is seen much more frequently as part of a syndrome. $\mathrm{ONH}$ is usually accompanied by other anterior segmental defects of the eye (MIM 607108), ${ }^{10}$ structural abnormalities of the brain, hypopituitarism (MIM 184429), ${ }^{11}$ developmental delay/intellectual disability, and autism spectrum disorders. ${ }^{12}$ This review will focus on the genetic mutations that are currently known to cause $\mathrm{ONH}$. Herein, we will define $\mathrm{ONH}$ broadly as any optic disc that shows decreased neuronal area and small optic nerves, congenitally. The reviews of the more narrowly defined septo-optic dysplasia (SOD), also known as de Morsier syndrome, can be found elsewhere. ${ }^{5613}$

To date, variants in genes involved in transcription regulation, chromatin remodelling, 
$\alpha$-dystroglycan glycosylation, cytoskeleton and scaffolding protein, RNA splicing, and the MAP kinase signalling pathway, have been associated with ONH. In the first part of the review, we will introduce the basic functions of the genes involved, the clinical features of the affected individuals and the animal models used to study the respective disorders. In the second part of the review, we will delineate the common developmental pathway shared by some of the key transcription factors in eye development.

\section{Transcription factors}

\section{HESX1}

HESX1 homeobox 1 (HESX1) encodes a homeobox protein, which plays an important role in normal forebrain development and the early determination and differentiation of the pituitary gland in murine models. ${ }^{14}$ Dattani et al reported the first genetic mutation in HESX1 (homozygous p.R160C) in a familial case (siblings from a consanguineous family) of SOD. ${ }^{15}$ SOD (MIM 182230) is defined by any combination of (1) ONH, (2) pituitary hypoplasia and (3) midline neuroradiological abnormalities, such as defects in the corpus callosum and septum pellucidum. Although the diagnosis of ONH in the study of Dattani et al remained controversial, ${ }^{13} 16$ subsequent novel heterozygous HESX1 mutations were identified in patients with $\mathrm{ONH}$ diagnosed with combined pituitary hormone deficiency ${ }^{17}$ or SOD. ${ }^{18}$ In addition, HESX1 constitutive knockout mice $\left(H e s x 1^{-/-}\right)$show substantial perinatal and postnatal lethality and display variable anterior central nervous system (CNS) defects and pituitary dysplasia. Anophthalmia, microphthalmia, defective olfactory development, and abnormalities in the corpus callosum, hippocampal commissures and septum pellucidum were described in Hes $x 1^{-/-}$mice, while the milder phenotype was found at very low frequency in Hes $x 1^{+/-}$mice (1\%). ${ }^{15}$

\section{PAX6}

Paired box gene 6 (PAX6) encodes a transcription factor that is involved in eye morphogenesis. It was first implicated in human aniridia, ${ }^{19}$ but later found to be involved in other eye anomalies, including microphthalmia, cataracts, foveal hypoplasia and $\mathrm{ONH}$ (MIM 607108). Although ONH is not common in individuals with PAX6 mutations, Azuma et al reported heterozygous PAX6 mutations (p.Q205X, p.S292I and p.M381V) in three individuals with $\mathrm{ONH}$, one of whom had intellectual disability. In the same study, they also identified heterozygous PAX6 mutations (p.Q378R and p.T391A) in two patients with optic nerve agenesis. ${ }^{10}$ Hingorani et $a l^{20}$ summarised ophthalmologic evaluations in 43 individuals with variable anomalies of the iris, carrying heterozygous mutations in PAX6. They reported nystagmus and foveal hypoplasia as the most common clinical findings, present in 41 and 37 individuals, respectively. In comparison, $\mathrm{ONH}$ was found in 10 individuals in this cohort, most of whom carried frameshift mutations. Given that PAX6 is also a master regulator of neurogenesis, ${ }^{21}$ abnormalities other than ocular defects have also been reported, including developmental delay, ${ }^{10}$ cognitive impairment, autism, epilepsy and structural brain abnormalities of white matter, mostly the corpus callosum. ${ }^{22}$

To date, more than 40 Pax6 mutant mouse models are available (Mouse Genome Informatics (http://www.informatics.jax. org/)), most of which have phenotypes affecting the eyes/vision, the nervous system, craniofacial development, and/or mortality. One of the first characterised Pax6 mouse models is the Sey/ Sey (Small eye) mouse. Sey/Sey pups are born without both eyes and nasal cavities, manifesting a high prevalence of perinatal mortality due to breathing problems, associated with the absence of the nose. ${ }^{23}$ Later studies showed the homozygous knockout animals also had forebrain defects. ${ }^{24}$ Heterozygous Sey/+ mice have milder phenotypes. These mice display microphthalmia, frequently with cataracts, which manifest within a few weeks of age, retinal abnormalities and partial or complete absence of the iris. ${ }^{25}$ The morphogenesis of the optic nerve is also affected in Sey/+ mice. The cross sectional area and the myelinated fibre counts of optic nerves are decreased significantly in heterozygous mice, a finding more severe in male than female mice; the mechanism is unclear. ${ }^{26}$

Similar to the mouse, a Pax6 mutant rat model, $r$ Sey2 (rat Small eye), shows that homozygotes $(r$ Sey/rSey) do not develop lens and nasal placodes and are perinatal lethal, while heterozygotes $(r S e y /+)$ have small eyes. ${ }^{27}$ Later in life, heterozygotes have impaired prepulse inhibition, altered social interaction and low performance in fear-conditioned memory tests, leading the authors to suggest an autism-like phenotype. ${ }^{28}$

The pleiotropic role of PAX6 during development can be appreciated through the detailed investigation of several Pax6 mutant mouse models. Pax6 consists of three functional domains: the paired domain (PD), the homeodomain (HD) and the transactivating proline-serine-threonine domain. Pax6 mutations in different functional domains yield different phenotypes. For example, Haubst et al compared the Pax $6^{4 \mathrm{Neu}}$ mutants (HD mutation) and Pax $6^{\text {Aey18 }}$ mutants (PD mutation), and found out that while the former had only subtle effects on forebrain development, the latter had severe impairment of neurogenesis, cell proliferation and patterning in the developing forebrain. ${ }^{29}$ The molecular consequences of Pax $6^{\text {Leca2 } 2}$ and Pax $6^{\text {Leca4 }}$ mutants, which carry point mutations in two different subdomains within the PD domain, also differed greatly. While Pax $6^{\text {Leca2 }}$ mutants increased the number of mitoses in the developing cerebral cortex, Pax $6^{\text {Leca } 4}$ mutants showed the opposite. Moreover, neurogenesis was only affected in $\operatorname{Pax}_{6}^{\text {Leca }}$, but not Pax6 $6^{\text {Leca2 }}$ mutants. ${ }^{30}$ With more than 400 unique human PAX6 variants reported to date (Leiden Open Variation Database (http://lsdb. hgu.mrc.ac.uk/home.php?select_db=PAX6)), and considering the diverse clinical phenotypes in human patients, the specific mutation needs to be considered to provide accurate diagnosis, counselling and management.

\section{SOX2}

SRY (sex determining region Y)-box 2 (SOX2) encodes a transcription factor essential for embryonic development of multiple organs, including brain and eyes. ${ }^{31}$ Heterozygous SOX2 mutations are the most common genetic cause for bilateral anophthalmia and severe microphthalmia. They account for 10\%-20\% of all patients with microphthalmia/anophthalmia. ${ }^{32-34}$ Among 235 individuals with congenital hypothalamic-pituitary disorders, Kelberman et $a l^{11}$ reported two patients (patient 7; p.G130A and patient 8; p.A191T) with bilateral ONH and nystagmus. They discussed the possible neutral nature of these two SOX2 variants, given that both were inherited from unaffected fathers, but it should be noted that incomplete penetrance for SOX2 mutations has been reported elsewhere. ${ }^{35}$ In the same study, another six patients with microphthalmia/ anophthalmia were found to carry de novo SOX2 mutations, and four out of five, for whom MRI data were available, showed either hypoplastic optic nerves or complete agenesis of the optic nerves. Other phenotypes included structural anomalies of the corpus callosum and hippocampus. Bakrania et $a l^{33}$ reported a female patient (case 2; p.N63fs101X) with unilateral ONH 
and cataract, atypical coloboma and esotropia in the other eye. The patient had a thin corpus callosum. Ragge et $a l^{36}$ reported two patients (case 6; p.L314fs436X and case 7; p.G23fs85X) with bilateral anophthalmia, attenuated optic nerves without visible chiasm, global developmental delay and malformation of the hippocampus. Jayakody et $a l^{37}$ reported a patient (patient 1; p.L97P) with bilateral microphthalmia, left sclerocornea and aphakia. MRI data showed right microphthalmos with a prosthesis in situ, a colobomatous left globe, and small optic nerves and chiasm.

Homozygous knockout of Sox 2 causes embryonal lethality in mice, with the products of conception dying shortly after implantation. Heterozygous knockout mice appear normal, except for decreased male fertility. ${ }^{38}$ Although heterozygous knockout mice do not seem to recapitulate the human eye phenotypes, Sox2 hypomorphic/null compound heterozygous adult mice (expressing $40 \%$ of Sox 2 compared with wild type) show hypoplasia of optic nerves and chiasmata, with eye phenotypes ranging from mild bilateral microphthalmia to severe anophthalmia, ${ }^{31}$ much like heterozygous patients. The authors argued that the striking similarity between heterozygous patients and compound heterozygous mouse models could be explained by species differences; alternatively, it has been suggested that humans with SOX2-related eye phenotypes may indeed be compound heterozygotes, carrying a null allele and a hypomorphic allele that brings the total functional level of SOX2 down to a range that results in phenotypic expression. ${ }^{31}$

\section{NR2F1}

Nuclear receptor subfamily 2 group F member 1 (NR2F1) encodes a conserved orphan nuclear receptor, which plays a critical role in cortical patterning, axon guidance, neurogenesis, and eye and optic nerve development. ${ }^{39}{ }^{40}$ We and others identified heterozygous NR2F1 mutations in individuals manifesting global developmental delay/intellectual disability and $\mathrm{ONH} /$ optic atrophy (Bosch-Boonstra-Schaaf Optic Atrophy syndrome, BBSOAS, MIM 615722). ${ }^{39} 4142$ The phenotypic spectrum of BBSOAS included hypotonia, seizures, autism, oromotor dysfunction, thinning of the corpus callosum and hearing defects. ${ }^{43}$ To date, pathogenic NR2F1 variants have been reported as missense, translation initiation variants, frameshifting indels and whole gene deletions. The missense mutations were enriched in the two functional domains of NR2F1: the DNA-binding domain (DBD) and the ligand-binding domain. Notably, patients with missense mutations in the DBD generally had more severe phenotypes compared with those carrying a heterozygous whole gene deletion. Given that NR2F1 binds to DNA in the form of dimers, ${ }^{44}$ a dominant negative effect may be the cause for this phenomenon. A genotype-phenotype correlation was proposed: patients with severe clinical phenotypes carry NR2F1 variants that tend to have almost completely blunted transcriptional activity, as assessed by in vitro luciferase assay. ${ }^{43}$

Homozygous knockout $\mathrm{Nr} 2 \mathrm{f1}^{-/-}$mice die within the first 2 days after birth due to starvation and dehydration. Defects in the formation of the glossopharyngeal nerve in $\mathrm{Nr} 2 \mathrm{f1}^{-/-}$pups have been proposed as the cause, ${ }^{45}$ and this observation may relate to the oromotor dysfunction seen in patients with BBSOAS. Abnormal development of the corpus callosum and the hippocampal commissure also is seen in embryonic $\mathrm{N} r 2 f 1^{-/-}$brains. ${ }^{46}$ Eye-specific double knockout of $\mathrm{Nr} 2 f 1$ and $\mathrm{Nr} 2 f 2$, a paralogue of $\mathrm{Nr} 2 f 1$, leads to ocular colobomata, microphthalmia and abnormal optic cups. The expression of several regulatory genes critical for early optic vesicle development, such as Pax6 and $\operatorname{Otx} 2$, is altered in double knockout mice, resulting in abnormal differentiation of the progenitor cells at the optic vesicle..$^{40}$ Although all the patients with BBSOAS identified so far carry heterozygous NR2F1 variants, a heterozygous knockout $\left(\mathrm{Nr} 2 \mathrm{fi}^{+-}\right)$mouse model has not been reported.

\section{OTX2}

Orthodenticle homeobox 2 (OTX2) encodes a HD-containing transcription factor that plays an important role in forebrain and eye development. ${ }^{47}$ Heterozygous mutations in OTX2 account for $2 \%-8 \%$ of patients with microphthalmia/anophthalmia, ${ }^{48} 49$ making them the second most common genetic cause of microphthalmia/anophthalmia (after SOX2). Using a candidate gene approach, Ragge et al first reported OTX2 variants in 11 affected individuals from eight families in a cohort diagnosed with ocular malformation spectrum defects. All of these eight probands had microphthalmia/anophthalmia. The optic nerves and chiasm were absent or reduced in four out of the six patients who had MRI, CT or ultrasound data available for review. ${ }^{50}$ Later studies showed that $35 \%$ of the patients with OTX2 mutations had ONH, while other eye defects such as coloboma and retinal dystrophies were less common. ${ }^{49}$ In addition to ocular abnormalities, the phenotypic spectrum of OTX2 mutations included structural and functional abnormalities of the pituitary, global developmental delay, autism, attention-deficit disorder, feeding difficulties, seizures, microcephaly and other structural brain anomalies, affecting the corpus callosum and hippocampus. ${ }^{49-51}$ Incomplete penetrance and variable expressivity have been reported for OTX2 mutations. In the original study, three out of six families with loss-of-function mutations inherited their variants from a phenotypically normal parent (two parents were constitutive mutation carriers, and one was gonosomal mosaic). Variable expressivity has been documented extensively, including individuals sharing the same variant, even among siblings. ${ }^{50}$ Homozygous knockout mice $\left(\mathrm{Ot} x 2^{-1-}\right)$ are embryonically lethal and display abnormal development of the forebrain, midbrain and rostral hindbrain. ${ }^{47}$ Heterozygous mice show variable phenotypes, including anencephaly, holoprosencephaly, microphthalmia/anophthalmia, micrognathia/agnathia, and short nose. ${ }^{52}$

\section{VAX1}

Ventral anterior homeobox 1 (VAX1) encodes a homeobox transcription factor, which plays an important role in the forebrain and visual system. ${ }^{53}$ Slavotinek $e t a l^{54}$ identified a homozygous missense VAX1 variant (p.R152S) in a screen of 70 individuals with microphthalmia/anophthalmia. The affected male patient was born to phenotypically normal, consanguineous parents, who were confirmed as heterozygous carriers of the variant. In addition to microphthalmia, other clinical features included ONH, global developmental delay, hippocampal malformations, agenesis of the pineal gland and corpus callosum, and cleft lip/ palate. Homozygous knockout $\operatorname{Vax}^{-/-}$mice are perinatally lethal, and the observed phenotypes bear remarkable similarity to the human patient: optic nerve dysgenesis, coloboma and abnormalities in brain structures (corpus callosum, hippocampus and anterior commissure). ${ }^{53}$ Heterozygous knockout Vax $1^{+/-}$ mice appear normal, except for subfertility. ${ }^{55}$

\section{ATOH7}

Atonal homologue BHLH transcription factor 7 (ATOH7) encodes a basic helix-loop-helix transcription factor, which is critical for retinal ganglion cell and optic nerve formation. ${ }^{56}$ Khan 
et al reported two homozygous $A T O H 7$ variants (one missense and the other as frameshift variant) in two consanguineous families with isolated microphthalmia. Two affected siblings from the family with frameshift mutations also displayed $\mathrm{ONH}$, corneal opacity and retinal detachment. Co-segregation of this mutation with the clinical phenotype was confirmed in the family. ${ }^{57}$ The finding was supported by two genome-wide association studies, which identified SNP ( $\mathrm{rs} 3858145, \mathrm{p}=3.4 \times 10^{-10}$ ) and SNP $\left(\mathrm{rs} 1900004, \mathrm{p}=2.67 \times 10^{-33}\right)$ within $20 \mathrm{~kb}$ and $10 \mathrm{~kb}$ of $A T O H 7$, respectively. ${ }^{585}$ However, pathogenic $A T O H 7$ variants were not discovered in an investigation of 34 patients with $\mathrm{ONH}^{60}$ and 76 other patients with microphthalmia/anophthalmia/coloboma. ${ }^{61}$ Homozygous knockout Atoh $7^{-/-}$mice are viable and fertile, and appear normal externally. Although they tend to have normalsized eyes, there is an $80 \%-95 \%$ reduction in the number of retinal ganglion cells, with very thin or absent optic nerves. ${ }^{56} 62$

\section{Chromatin remodelling}

\section{KANSL1 (17q21.31 microdeletion)}

KAT8 regulatory NSL complex subunit 1 (KANSL1) encodes a nuclear protein that is a key component of a histone acetyltransferase complex. ${ }^{63}$ KANSL 1 is one of the five known proteincoding genes in the $17 \mathrm{q} 21.31$ microdeletion syndrome locus (MIM 610443). It was later found that haploinsufficiency of KANSL1 was sufficient to cause the phenotypes of $17 \mathrm{q} 21.31$ microdeletion syndrome, also known as Koolen-de Vries syndrome (KdVS). ${ }^{64} \mathrm{KdVS}$ is a multisystem disorder, characterised by developmental delay/intellectual disability, hypotonia and characteristic facial dysmorphism. Additional features include overly social and friendly behaviour, epilepsy, congenital heart defects, urogenital malformations, musculoskeletal anomalies and ectodermal anomalies. Zollino et al reported a deletion patient (patient 28) with hypoplastic ocular globe, unilateral ONH, strabismus, hearing impairment and craniosynostosis. ${ }^{65}$ Koolen et al reported another deletion patient (case 32) with $\mathrm{ONH}$, hypermetropia, strabismus, esotropia and corpus callosum abnormality. ${ }^{66}$ The third deletion patient reported manifested cataracts, optic atrophy, hearing impairment and a small hippocampus. ${ }^{67}$ Currently no mouse model for Kansl1 deletion exists. Knockout of wah (KANSL1 orthologue in Drosophila) is embryonal lethal in flies. Tissue-specific knockdown of wah in muscles and mushroom bodies (the learning and memory centres in Drosophila brains) leads to neuromuscular-junction defects and decreased learning ability. ${ }^{64} 68$ The function of wah in eye development is unknown currently.

\section{$\alpha$-Dystroglycan glycosylation}

\section{B3GALNT2}

Beta-1,3-N-Acetylgalactosaminyltransferase 2 (B3GALNT2) encodes a glycosyltransferase that helps synthesise $\alpha$-dystroglycan, which is an integral component of the dystrophin glycoprotein complex. Defects in glycosylation reduce the binding ability of $\alpha$-dystroglycan to extracellular matrix ligands, causing a dystroglycanopathy. Stevens et al reported seven individuals with congenital muscular dystrophy-dystroglycanopathy, and a phenotype defined as 'brain and eye anomalies type A11' (MDDGA11, MIM 615181). These individuals carried either homozygous or compound heterozygous mutations in B3GALNT2. Two of the affected individuals had ONH. Currently, there is no murine model for B3galnt2 loss-of-function studies; however, knockdown of b3galnt2 in zebrafish showed retinal degeneration, impaired motility and brain abnormalities. ${ }^{69}$

\section{ISPD}

Isoprenoid synthase domain-containing protein (ISPD) encodes a protein that is required for proper $\alpha$-dystroglycan modification. Similar to B3GALNT2, ISPD mutations were identified in patients diagnosed with congenital muscular dystrophy-dystroglycanopathy with brain and eye anomalies, in this case type A7 (MDDGA7, MIM 614643). Willer et al reported seven individuals, including a pair of siblings, carrying homozygous or compound heterozygous mutations in ISPD. Two of the seven patients had $\mathrm{ONH}$. One of the affected siblings was diagnosed with bilateral $\mathrm{ONH}$, and the other had bilateral microphthalmia (status of optic nerves not mentioned in the study). ${ }^{70}$ Roscioli et al identified two individuals with MDDGA7, one with a homozygous and the other with compound heterozygous mutations in ISPD. However, instead of being described with $\mathrm{ONH}$, they were diagnosed with optic atrophy. ${ }^{71}$ The four individuals also shared brain malformations, including hydrocephalus, cerebellar hypoplasia and cobblestone lissencephaly. In a forward genetic screen for axon guidance defects in mice, it was found that homozygous loss-of-function Ispd $d^{L 79^{*} / L 79^{*}}$ (leucine to premature stop codon) leads to neonatal lethality, abnormal axon guidance in the hindbrain and abnormal fasciculation of the funiculus of the spinal cord. However, eye-related phenotypes were not reported in that mouse study. ${ }^{72}$

\section{Cytoskeleton and scaffolding protein}

\section{TUBA8}

Tubulin alpha 8 (TUBA8) encodes a member of the $\alpha$-tubulin protein family. $\alpha$-Tubulins and $\beta$-tubulins heterodimerise and then assemble to form microtubules. Abdollahi et $a l^{73}$ reported homozygous indel in an intron of TUBA8 in three affected members of a consanguineous Pakistani family. The same homozygous deletion was found in an affected child from a second Pakistani family. The $14 \mathrm{bp}$ deletion lies $11 \mathrm{bp}$ upstream of the exon 2 splice junction. The deletion was predicted to interfere with correct splicing, which was verified by the reverse transcription PCR of lymphoblastoid cell line RNA from the patient. All four affected children have ONH with polymicrogyria, seizures, thin or absent corpus callosum and brainstem abnormalities. Surprisingly, expression of Tuba8 is relatively low in developing mouse and human brains, even though the clinical phenotypes mainly present as brain malformations. ${ }^{74}$ Currently, no mouse model exists for Tuba 8 mutations.

\section{CASK}

Calcium/calmodulin-dependent serine protein kinase (CASK) encodes a member of the membrane-associated guanylate kinase (MAGUK) protein family, which consists of scaffolding proteins associated with intercellular junctions. ${ }^{75}$ Heterozygous or hemizygous mutations in the X-linked CASK gene in patients lead to microcephaly with pontine and cerebellar hypoplasia $(\mathrm{MICPCH}$, MIM 300749). ${ }^{76}$ The phenotypic spectrum of CASK mutations includes autistic traits, developmental delay/intellectual disability, axial hypotonia and/or peripheral hypertonia, movement and behavioural disorders, and seizures. Although $\mathrm{ONH} /$ optic atrophy is not fully expressed in patients with $\mathrm{MICPCH}$, it has been reported in multiple studies. ${ }^{778}$ Other ophthalmological abnormalities include hyperopia, strabismus, astigmatism and nystagmus. Constitutive knockout mice $\left(\mathrm{Cask}^{-/ y}\right.$ and Cask $^{-1-}$ ) die within the first day after birth, ${ }^{75}$ but deletion of a single Cask allele $\left(\mathrm{Cask}^{+/-}\right)$in female mice has been found to recapitulate many human phenotypes, including microcephaly, hypotonia, ataxia and $\mathrm{ONH}$ without microphthalmia 
or malformation of the brain midline. ${ }^{79}$ The study suggested that Cask regulates oxidative metabolism in the brain, and the rate of glucose oxidation was reduced by $20 \%$ in the brain of Cask ${ }^{+/-}$ mice compared with wild-type littermates. ${ }^{79}$

\section{RNA splicing} PUF60

Poly(U) binding splicing factor 60 (PUF60) encodes a ribonucleoprotein-binding protein, which is involved in pre-mRNA splicing and transcriptional regulation. Dauber et $a l^{80}$ identified the first patient with a de novo heterozygous variant, p.H169Y in PUF60. El Chehadeh et $a l^{81}$ reported another five patients with de novo heterozygous variants in PUF60. All six patients identified to date manifest the same facial gestalt as seen in individuals with 8q24.3 microdeletion syndrome, also known as Verheij syndrome (MIM 615583). Other shared clinical features include bilateral ONH (2/6), developmental delay (6/6), cardiac defects (5/6), short stature (5/6), joint laxity and/or dislocation $(5 / 6)$, vertebral anomalies (3/6) and feeding difficulties (3/6). Currently, there is no mouse model for Puf60 mutations.

\section{MAPK signalling pathway}

BRAF

B-Raf proto-oncogene (BRAF) encodes a serine/threonine-protein kinase that plays a role in regulating the MAP kinase signalling pathway. Mutations in BRAF are one of the causes of cardio-facio-cutaneous (CFC) syndrome (MIM 115150). Armour and Allanson reported 38 individuals with CFC, 32 of which had autosomal dominant variants in $B R A F$. The remaining six individuals carried either MEK1 or MEK2 variants. Among the patients with $B R A F$ mutations, $\mathrm{ONH} /$ dysplasia was diagnosed in 9 out of the 20 individuals who had provided ophthalmological assessments for review. Meanwhile, two out of six individuals carrying MEK1 or MEK2 variants had such diagnoses. ${ }^{82}$ MEK1, MEK2 and BRAF are integral parts of the MAP kinase pathway. Although the signs of CFC overlap substantially with Noonan syndrome, it was estimated that only 2\% (3/139) of patients with Noonan syndrome had ONH. ${ }^{83}$ As most BRAF mutations in CFC are predicted to be gain of function, multiple corresponding mouse models have been generated. Braf $f^{+/ V 600 E}$ and $\mathrm{Braf}^{+/ L 597 \mathrm{~V}}$ mouse models, both carrying an allele expressing constitutively active Braf protein, recapitulate certain patient phenotypes, including small body size, facial dysmorphism, cardiomegaly and eye abnormalities (cataracts). ${ }^{84} 85$

\section{Others}

\section{ALDH1A3}

Aldehyde dehydrogenase one family member A3 (ALDH1A3) encodes an aldehyde dehydrogenase enzyme that uses retinal (retinaldehyde) as a substrate to synthesise retinoic acid, which plays a critical role in eye development. ${ }^{86}$ Fares-Taie et al ${ }^{87}$ identified two homozygous missense mutations (p.R89C and p.A493P) and one homozygous splice-site mutation in four individuals from three consanguineous families. These mutations segregated with microphthalmia/anophthalmia along with occasional orbital cystic, neurological and cardiac anomalies in the family. Available MRI data from two individuals showed hypoplastic optic nerves. Yahyavi et $a^{88}$ identified a homozygous nonsense mutation, p.L389*, which they predicted to cause nonsense-mediated decay, in a patient with microphthalmia/anophthalmia and hypoplasia of the optic nerve and optic chiasm. Homozygous knockout Aldh $1 a 3^{-/-}$mice are lethal perinatally and show defects in the invagination of the ventral optic cup, closure of the choroid fissures and abnormal axonal projections of retinal cells into the brain. ${ }^{8689}$ Interestingly, Aldh1a3 is also critical for the development of nasal structures, and null mice die of respiratory distress at birth, resulting from choanal atresia (blockage of nasal passage). However, all the human patients reported to date do not display these nasal or choanal abnormalities, suggesting residual protein function of the pathogenic alleles, or species-dependent differences in mice versus humans.

\section{DDHD2}

DDHD domain-containing protein 2 (DDHD2) encodes a phospholipase enzyme and is a major brain triglyceride hydrolase. Schuurs-Hoeijmakers et $a l^{90}$ reported five individuals diagnosed with complex hereditary spastic paraplegia (SPG54, MIM 615033 ) carrying biallelic mutations in DDHD2. Three out of five individuals had ONH. Other shared features included developmental delay/intellectual disability, hypotonia, strabismus and thin corpus callosum. Ddhd 2 constitutive knockout mice $\left(D d h d 2^{-/-}\right)$exhibit defects in movement and cognitive function, and show selective elevation in triacylglycerols through the CNS. However, the visual ability in these mice is not different substantially from wild-type controls in the optomotor test. ${ }^{91}$

\section{DISCUSSION}

\section{Molecular network of transcription factors in eye development}

Eye morphogenesis in vertebrates is an intricate multistep process, including the formation of the eye pit, optic vesicle, optic cup, lens and neurogenesis in the neural retina (NR) (figure 1). Many key transcription factors participate in these sequential events to ensure the proper formation and maturation of the eye. ${ }^{92}$ While most knowledge described here is derived from murine studies, a high level of conservation exists for the sequence and function of these key transcription factors in eye development between human and murine models, so the described processes carry significance in humans as well. In mice, the evagination of optic pits leads to the formation of the early optic vesicle at E9.5. Then, the invagination of optic vesicle at E10.5 results in the formation of a dual-layered optic cup, which consists of three main domains: the NR, retinal pigment epithelium and optic stalk (OS). The OS later becomes the optic nerve when the axons of the retinal ganglion cells fill the cavity of the stalk and complete the closure of the choroid fissure (figure 1).

The boundary between OS and NR is established at the optic disc, which serves an entrance for the blood vessels to the eye and as an exit for the axons of retinal ganglion cells from the eye. Pax6, an NR marker, and Pax2, a ventral OS marker, antagonise each other to establish the sharp boundary (figure 1). ${ }^{93}$ Reciprocal expansion of Pax2 and Pax6 gene expressions is seen in the corresponding loss-of-function mutant mice. Disruption of this boundary causes defects in the optic nerve, OS, retina, lens and optic fissure closure. ${ }^{94} 95$ Vax1 and Vax2 are also involved in the boundary formation by inhibiting Pax 6 expression, given that the expression of Pax 6 and Pax 2 is rapidly acquired and lost from the OS in Vax1 and Vax2 double knockouts at E10. ${ }^{96}$

Another example of boundary formation defects is reported in $N r 2 f 1$ and $N r 2 f 2$ double knockout mice. Increased expression of Pax6 in NR and decreased expression of Pax2 in ventral OS, accompanied by reduced expression of Vax 1 in the OS, shift the NR-vOS boundary proximally, eventually leading to abnormal differentiation of the OS. ${ }^{40}$ These data suggested that $\mathrm{Nr} 2 \mathrm{f} 1$ and $\mathrm{Nr} 2 \mathrm{f} 2$ are the key regulators that balance the expression of Pax6 and Pax 2 during the early development of the optic cup. 


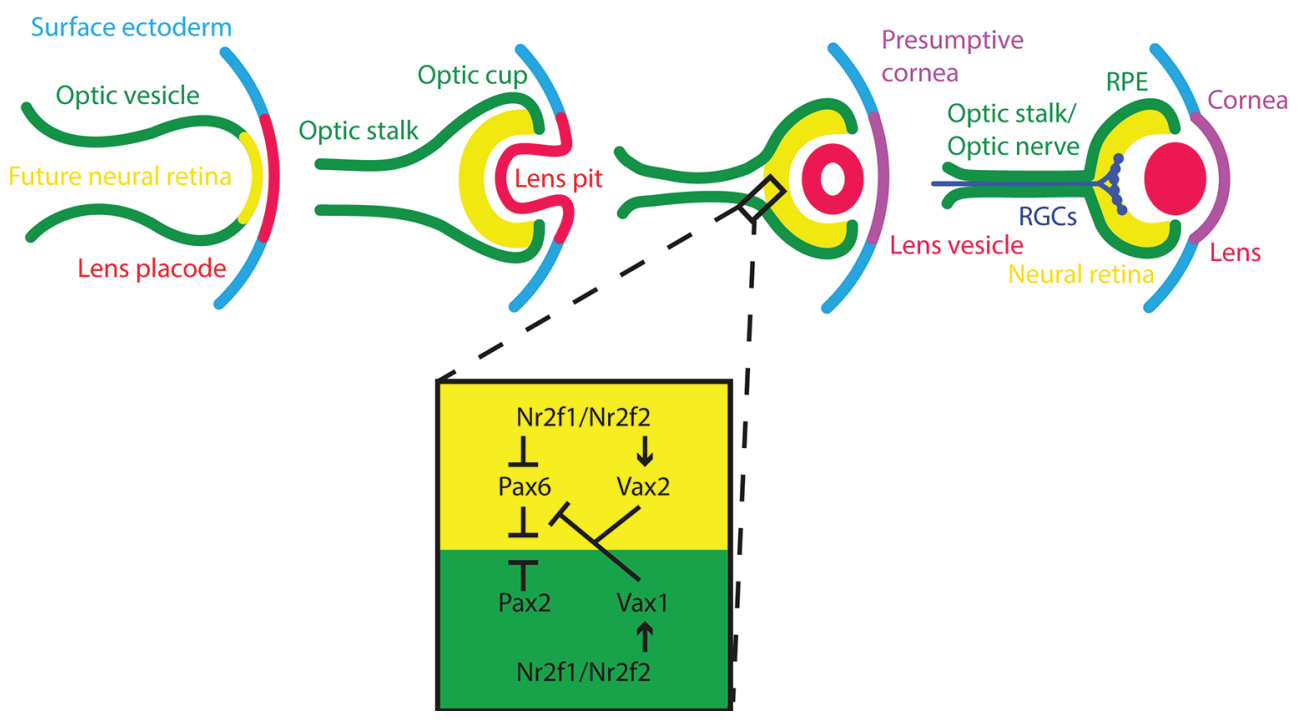

Figure 1 Eye development and key transcription factors. In early eye development, the evagination of optic pits leads to the formation of the early optic vesicle. The surface ectoderm and the underlying neuroepithelium invaginate to form the lens vesicle and bilayered optic cup, respectively. The outer layer of the optic cup gives rise to the retinal pigment epithelium, while the inner layer gives rise to the neural retina. The optic stalk later becomes the optic nerve when the axons of the retinal ganglion cells fill the cavity of the stalk and complete the closure of the choroid fissure. Many key transcription factors, mutations of which cause $\mathrm{ONH}$, participate in the proper development of the optic stalk/optic nerve. ONH, optic nerve hypoplasia; RGC, retinal ganglion cell; RPE, retinal pigment epithelium.

However, the eye phenotypes in the individuals with heterozygous PAX6 mutations are generally more severe than those with heterozygous NR2F1 mutations. This could be explained by the functional redundancy between NR2F1 and NR2F2, given that eye-specific double knockout of $\mathrm{Nr} 2 f 1$ and $\mathrm{Nr} 2 f 2$ in mice leads to major eye abnormalities but does not do so in eye-specific single knockout of $\mathrm{Nr} 2 f 1^{40}$

Two transcription factors synergistically regulating lens development are Pax6 and Sox2, again indicating the intricate interaction between transcription factors during eye development. ${ }^{97}$

${ }^{98}$ Pax 6 and Sox 2 form a co-DNA-binding complex, which activates cooperatively the lens-specific enhancer element DC5 in order to differentiate embryonic ectoderm into lens ectoderm. In contrast to the synergistic relationship, the same two transcription factors antagonise each other in the developing optic cup to specify the multipotent optic cup progenitors towards a neurogenic fate (Sox2) or a non-neurogenic fate (Pax6). ${ }^{99}$ This suggests that the interplay between transcription factors may be highly cell-type specific and developmental stage specific during eye development.

Adding to the complexity of eye development is the fact that the aforementioned transcription factors are also involved in the morphogenesis of the forebrain and other brain regions, such as the midline brain, hypothalamus and pituitary gland. This involvement may explain why $\mathrm{ONH}$ is more commonly a part of a syndrome involving other structural brain anomalies, rather than an isolated finding. Similarly, most mutant mouse models manifest more extensive systemic defects, in addition to isolated $\mathrm{ONH}$. To date, multiple genes are implicated in $\mathrm{ONH}$; however, most of them are associated with other eye anomalies and/or brain structural defects. Nevertheless, the possibility that one single gene mutation leads to isolated $\mathrm{ONH}$ should not be discounted.

\section{CONCLUSION}

With ONH being the second most common cause of congenital visual impairment, ${ }^{100}$ the investigation of the causes and risk factors of $\mathrm{ONH}$ is of great importance. Although previous studies had mostly attributed ONH to the prenatal environment, the identification of an increasing number of genetic causes of $\mathrm{ONH}$ suggests multiple aetiological mechanisms, including gene-environment interactions, as well as monogenic causes with high penetrance. The consideration of gene-environment interactions and potential genetic modifiers is based, in part, on the presence of variable expressivity of related phenotypes among individuals carrying the same genetic variants.

Eye morphogenesis in mammalian species is an intricate process. Many key transcription factors relevant for eye development also play roles in the morphogenesis of forebrain. This interplay causes more complex clinical phenotypes, many of which involve cognitive deficits and behavioural alterations. With the advancement and clinical availability of genome-wide sequencing technology, we anticipate that more genes will be implicated in the aetiology of ONH. In some cases, the modes of inheritance may go well beyond Mendelian genetics, for example, digenic or oligogenic inheritance. These steps will lead to an increased molecular diagnostic rate for individuals with $\mathrm{ONH}$ per se. Additional research will investigate whether the functional consequences associated with the respective disorders are all due to structural deficits from altered neurodevelopment, or whether some function(s) could be regained, with therapeutic intervention, even started later in life.

Contributors CAC wrote the manuscript. JY created the figure. RAL edited the manuscript. CPS conceived and edited the manuscript.

Competing interests None declared.

Provenance and peer review Commissioned; externally peer reviewed.

(C) Article author(s) (or their employer(s) unless otherwise stated in the text of the article) 2017. All rights reserved. No commercial use is permitted unless otherwise expressly granted.

\section{REFERENCES}

1 Magnus H. Zur Karuistik der angelborenen Schnerven-milbildungen. Klin Monbl Augenheilkd. 1884;2:85-87.

2 Briere W, Absence des papiller, cecite absolue. Ann Ocul 1877;78:41-2.

3 Schwarz 0. Ein fall von mangelhafter bildung (Hypoplasie) beider sehnerven. Albrecht Von Graefes Arch Ophthalmol 1915;90:326-8. 
4 Steinkuller PG, Du L, Gilbert C, Foster A, Collins ML, Coats DK. Childhood blindness. J Aapos 1999;3:26-32.

5 Ryabets-Lienhard A, Stewart C, Borchert M, Geffner ME. The optic nerve hypoplasia spectrum: review of the literature and clinical guidelines. Adv Pediatr 2016;63:127-46

6 Garcia-Filion P, Borchert M. Optic nerve hypoplasia syndrome: a review of the epidemiology and clinical associations. Curr Treat Options Neurol 2013;15:78-89.

7 Cidis MB, Warshowsky JH, Goldrich SG, Meltzer CC. Mirror-image optic nerve dysplasia with associated anisometropia in identical twins. J Am Optom Assoc 1997;68:325-9.

8 Benner JD, Preslan MW, Gratz E, Joslyn J, Schwartz M, Kelman S. Septo-optic dysplasia in two siblings. Am J Ophthalmol 1990;109:632-7.

9 Ouvrier R, Billson F. Optic nerve hypoplasia: a review. J Child Neurol 1986;1:181-8.

10 Azuma N, Yamaguchi Y, Handa H, Tadokoro K, Asaka A, Kawase E, Yamada M. Mutations of the PAX6 gene detected in patients with a variety of optic-nerve malformations. Am J Hum Genet 2003;72:1565-70.

11 Kelberman D, Rizzoti K, Avilion A, Bitner-Glindzicz M, Cianfarani S, Collins J, Chong WK, Kirk JM, Achermann JC, Ross R, Carmignac D, Lovell-Badge R, Robinson IC, Dattani MT. Mutations within Sox2/SOX2 are associated with abnormalities in the hypothalamo-pituitary-gonadal axis in mice and humans. J Clin Invest 2006;116:2442-55.

12 Parr JR, Dale NJ, Shaffer LM, Salt AT. Social communication difficulties and autism spectrum disorder in young children with optic nerve hypoplasia and/or septo-optic dysplasia. Dev Med Child Neurol 2010;52:917-21.

13 Garcia-Filion P, Borchert M. Prenatal determinants of optic nerve hypoplasia: review of suggested correlates and future focus. Surv Ophthalmol 2013;58:610-9.

14 Martinez-Barbera JP, Rodriguez TA, Beddington RS. The homeobox gene Hesx 1 is required in the anterior neural ectoderm for normal forebrain formation. Dev Biol 2000;223:422-30.

15 Dattani MT, Martinez-Barbera JP, Thomas PQ, Brickman JM, Gupta R, Mårtensson IL, Toresson H, Fox M, Wales JK, Hindmarsh PC, Krauss S, Beddington RS, Robinson IC. Mutations in the homeobox gene HESX1/Hesx1 associated with septo-optic dysplasia in human and mouse. Nat Genet 1998;19:125-33.

16 Wales JK, Quarrell OW. Evidence for possible mendelian inheritance of septo-optic dysplasia. Acta Paediatr 1996:85:391-2.

17 Tajima T, Hattorri T, Nakajima T, Okuhara K, Sato K, Abe S, Nakae J, Fujieda K. Sporadic heterozygous frameshift mutation of HESX1 causing pituitary and optic nerve hypoplasia and combined pituitary hormone deficiency in a Japanese patient. Clin Endocrinol Metab 2003:88:45-50.

18 Cohen RN, Cohen LE, Botero D, Yu C, Sagar A, Jurkiewicz M, Radovick S. Enhanced repression by HESX 1 as a cause of hypopituitarism and septooptic dysplasia. J Clin Endocrinol Metab 2003:88:4832-9.

19 Jordan T, Hanson I, Zaletayev D, Hodgson S, Prosser J, Seawright A, Hastie N, van Heyningen $\mathrm{V}$. The human PAX6 gene is mutated in two patients with aniridia. Nat Genet 1992;1:328-32.

20 Hingorani M, Williamson KA, Moore AT, van Heyningen V. Detailed ophthalmologic evaluation of 43 individuals with PAX6 mutations. Invest Ophthalmol Vis Sci 2009:50:2581-90.

21 Paridaen JT, Huttner WB. Neurogenesis during development of the vertebrate centra nervous system. EMBO Rep 2014;15:351-64.

22 Davis LK, Meyer KJ, Rudd DS, Librant AL, Epping EA, Sheffield VC, Wassink TH. Pax6 3' deletion results in aniridia, autism and mental retardation. Hum Genet 2008; 123:371-8

23 Hill RE, Favor J, Hogan BL, Ton CC, Saunders GF, Hanson IM, Prosser J, Jordan T, Hastie ND, van Heyningen V. Mouse small eye results from mutations in a paired-like homeobox-containing gene. Nature 1991;354:522-5.

24 Stoykova A, Fritsch R, Walther C, Gruss P. Forebrain patterning defects in small eye mutant mice. Development 1996;122:3453-65.

25 van der Meer-de Jong R, Dickinson ME, Woychik RP, Stubbs L, Hetherington C, Hogan BL. Location of the gene involving the small eye mutation on mouse chromosome 2 suggests homology with human aniridia 2 (AN2). Genomics 1990;7:270-5.

26 Dangata YY, Findlater GS, Dhillon B, Kaufman MH. Morphometric study of the optic nerve of adult normal mice and mice heterozygous for the small eye mutation (Sey/+). J Anat 1994;185:627-35.

27 Matsuo T, Osumi-Yamashita N, Noji S, Ohuchi H, Koyama E, Myokai F, Matsuo $\mathrm{N}$, Taniguchi S, Doi H, Iseki S. A mutation in the Pax-6 gene in rat small eye is associated with impaired migration of midbrain crest cells. Nat Genet 1993:3:299-304.

28 Umeda T, Takashima N, Nakagawa R, Maekawa M, Ikegami S, Yoshikawa T, Kobayashi K, Okanoya K, Inokuchi K, Osumi N. Evaluation of Pax6 mutant rat as a model for autism. PLoS One 2010;5:e15500.

29 Haubst N, Berger J, Radjendirane V, Graw J, Favor J, Saunders GF, Stoykova A, Götz M. Molecular dissection of Pax6 function: the specific roles of the paired domain and homeodomain in brain development. Development 2004;131:6131-40.

30 Walcher T, Xie Q, Sun J, Irmler M, Beckers J, Öztürk T, Niessing D, Stoykova A, Cvek A, Ninkovic J, Götz M. Functional dissection of the paired domain of Pax6 reveals molecular mechanisms of coordinating neurogenesis and proliferation. Development 2013;140:1123-36.
31 Taranova OV, Magness ST, Fagan BM, Wu Y, Surzenko N, Hutton SR, Pevny LH. SOX2 is a dose-dependent regulator of retinal neural progenitor competence. Genes Dev 2006;20:1187-202

32 Fantes J, Ragge NK, Lynch SA, McGill NI, Collin JR, Howard-Peebles PN, Hayward C, Vivian AJ, Williamson K, van Heyningen V, FitzPatrick DR. Mutations in SOX2 cause anophthalmia. Nat Genet 2003;33:461-3.

33 Bakrania P, Robinson DO, Bunyan DJ, Salt A, Martin A, Crolla JA, Wyatt A, Fielder A, Ainsworth J, Moore A, Read S, Uddin J, Laws D, Pascuel-Salcedo D, Ayuso C, Allen L, Collin JR, Ragge NK. SOX2 anophthalmia syndrome: 12 new cases demonstrating broader phenotype and high frequency of large gene deletions. $\mathrm{Br} J$ Ophthalmol 2007:91:1471-6.

34 Gerth-Kahlert C, Williamson K, Ansari M, Rainger JK, Hingst V, Zimmermann T, Tech S, Guthoff RF, van Heyningen V, Fitzpatrick DR. Clinical and mutation analysis of 51 probands with anophthalmia and/or severe microphthalmia from a single center. Mol Genet Genomic Med 2013;1:15-31.

35 Zhou J, Kherani F, Bardakjian TM, Katowitz J, Hughes N, Schimmenti LA, Schneider A, Young TL. Identification of novel mutations and sequence variants in the SOX2 and CHX10 genes in patients with anophthalmia/microphthalmia. Mol Vis 2008;14:583-92.

36 Ragge NK, Lorenz B, Schneider A, Bushby K, de Sanctis L, de Sanctis U, Salt A, Collin JR, Vivian AJ, Free SL, Thompson P, Williamson KA, Sisodiya SM, Heyningen van V, Fitzpatrick DR. SOX2 anophthalmia syndrome. Am J Med Genet 2005:135:1-7.

37 Jayakody SA, Andoniadou CL, Gaston-Massuet C, Signore M, Cariboni A, Bouloux PM, Le Tissier P, Pevny LH, Dattani MT, Martinez-Barbera JP. SOX2 regulates the hypothalamic-pituitary axis at multiple levels. J Clin Invest 2012;122:3635-46.

38 Avilion AA, Nicolis SK, Pevny LH, Perez L, Vivian N, Lovell-Badge R. Multipotent cell lineages in early mouse development depend on SOX2 function. Genes Dev 2003:17:126-40.

39 Bosch DG, Boonstra FN, Gonzaga-Jauregui C, Xu M, de Ligt J, Jhangiani S, Wiszniewski W, Muzny DM, Yntema HG, Pfundt R, Vissers LE, Spruijt L, Blokland EA, Chen CA, Lewis RA, Tsai SY, Gibbs RA, Tsai MJ, Lupski JR, Zoghbi HY, Cremers FP, de Vries BB, Schaaf CP. NR2F1 mutations cause optic atrophy with intellectual disability. Am J Hum Genet 2014:94:303-9.

40 Tang K, Xie X, Park Jl, Jamrich M, Tsai S, Tsai MJ. COUP-TFs regulate eye development by controlling factors essential for optic vesicle morphogenesis. Development 2010;137:725-34.

41 Brown KK, Alkuraya FS, Matos M, Robertson RL, Kimonis VE, Morton CC. NR2F1 deletion in a patient with a de novo paracentric inversion, inv(5)(q15q33.2), and syndromic deafness. American journal of medical genetics Part A 2009:149A:931-8.

42 Al-Kateb H, Shimony JS, Vineyard M, Manwaring L, Kulkarni S, Shinawi M. NR2F1 haploinsufficiency is associated with optic atrophy, dysmorphism and global developmental delay. Am J Hum Genet 2013;161A:377-81.

43 Chen CA, Bosch DG, Cho MT, Rosenfeld JA, Shinawi M, Lewis RA, Mann J, Jayakar P, Payne K, Walsh L, Moss T, Schreiber A, Schoonveld C, Monaghan KG, Elmslie F, Douglas G, Boonstra FN, Millan F, Cremers FP, McKnight D, Richard G, Juusola J, Kendall F, Ramsey K, Anyane-Yeboa K, Malkin E, Chung WK, Niyazov D, Pascual JM, Walkiewicz M, Veluchamy V, Li C, Hisama FM, de Vries BB, Schaaf C. The expanding clinical phenotype of Bosch-Boonstra-Schaaf optic atrophy syndrome: 20 new cases and possible genotype-phenotype correlations. Genet Med 2016:18:1143-50.

44 Cooney AJ, Tsai SY, O'Malley BW, Tsai MJ. Chicken ovalbumin upstream promoter transcription factor (COUP-TF) dimers bind to different GGTCA response elements, allowing COUP-TF to repress hormonal induction of the vitamin D3, thyroid hormone, and retinoic acid receptors. Mol Cell Biol 1992;12:4153-63.

45 Qiu Y, Pereira FA, DeMayo FJ, Lydon JP, Tsai SY, Tsai MJ. Null mutation of mCOUPTFI results in defects in morphogenesis of the glossopharyngeal ganglion, axonal projection, and arborization. Genes Dev 1997;11:1925-37.

46 Armentano M, Filosa A, Andolfi G, Studer M. COUP-TFI is required for the formation of commissural projections in the forebrain by regulating axonal growth. Development 2006;133:4151-62.

47 Acampora D, Mazan S, Lallemand Y, Avantaggiato V, Maury M, Simeone A Brûlet P. Forebrain and midbrain regions are deleted in $0 t \times 2^{-/-}$mutants due to a defective anterior neuroectoderm specification during gastrulation. Development 1995; 121:3279-90.

48 Wyatt A, Bakrania P, Bunyan DJ, Osborne RJ, Crolla JA, Salt A, Ayuso C, NewburyEcob R, Abou-Rayyah Y, Collin JR, Robinson D, Ragge N. Novel heterozygous OTX2 mutations and whole gene deletions in anophthalmia, microphthalmia and coloboma. Hum Mutat 2008;29:E278-83.

49 Schilter KF, Schneider A, Bardakjian T, Soucy JF, Tyler RC, Reis LM, Semina EV. OTX2 microphthalmia syndrome: four novel mutations and delineation of a phenotype. Clin Genet 2011;79:158-68.

50 Ragge NK, Brown AG, Poloschek CM, Lorenz B, Henderson RA, Clarke MP, RussellEggitt I, Fielder A, Gerrelli D, Martinez-Barbera JP, Ruddle P, Hurst J, Collin JR, Salt A, Cooper ST, Thompson PJ, Sisodiya SM, Williamson KA, Fitzpatrick DR, van Heyningen $\mathrm{V}$, Hanson IM. Heterozygous mutations of OTX2 cause severe ocular malformations. Am J Hum Genet 2005;76:1008-22.

51 Ashkenazi-Hoffnung L, Lebenthal Y, Wyatt AW, Ragge NK, Dateki S, Fukami M, Ogata T, Phillip M, Gat-Yablonski G. A novel loss-of-function mutation in OTX2 in 
a patient with anophthalmia and isolated growth hormone deficiency. Hum Genet 2010;127:721-9.

52 Matsuo I, Kuratani S, Kimura C, Takeda N, Aizawa S. Mouse Otx2 functions in the formation and patterning of rostral head. Genes Dev 1995:9:2646-58.

53 Hallonet M, Hollemann T, Pieler T, Gruss P. Vax1, a novel homeobox-containing gene, directs development of the basal forebrain and visual system. Genes Dev 1999;13:3106-14.

54 Slavotinek AM, Chao R, Vacik T, Yahyavi M, Abouzeid H, Bardakjian T, Schneider A Shaw G, Sherr EH, Lemke G, Youssef M, Schorderet DF. VAX1 mutation associated with microphthalmia, corpus callosum agenesis, and orofacial clefting: the first description of a VAX1 phenotype in humans. Hum Mutat 2012;33:364-8.

55 Hoffmann HM, Tamrazian A, Xie H, Pérez-Millán MI, Kauffman AS, Mellon PL. Heterozygous deletion of ventral anterior homeobox (vax1) causes subfertility in mice. Endocrinology 2014;155:4043-53.

56 Brown NL, Patel S, Brzezinski J, Glaser T. Math5 is required for retinal ganglion cell and optic nerve formation. Development 2001;128:2497-508.

57 Khan K, Logan CV, McKibbin M, Sheridan E, Elçioglu NH, Yenice O, Parry DA, Fernandez-Fuentes N, Abdelhamed ZI, Al-Maskari A, Poulter JA, Mohamed MD, Carr IM, Morgan JE, Jafri H, Raashid Y, Taylor GR, Johnson CA, Inglehearn CF, Toomes C, Ali M. Next generation sequencing identifies mutations in atonal homolog 7 (ATOH7) in families with global eye developmental defects. Hum Mol Genet 2012;21:776-83.

58 Macgregor S, Hewitt AW, Hysi PG, Ruddle JB, Medland SE, Henders AK, Gordon SD, Andrew T, McEvoy B, Sanfilippo PG, Carbonaro F, Tah V, Li YJ, Bennett SL, Craig JE, Montgomery GW, Tran-Viet KN, Brown NL, Spector TD, Martin NG, Young TL, Hammond CJ, Mackey DA. Genome-wide association identifies ATOH7 as a major gene determining human optic disc size. Hum Mol Genet 2010;19:2716-24.

59 Ramdas WD, van Koolwijk LM, Ikram MK, Jansonius NM, de Jong PT, Bergen AA, Isaacs A, Amin N, Aulchenko YS, Wolfs RC, Hofman A, Rivadeneira F, Oostra BA, Uitterlinden AG, Hysi P, Hammond CJ, Lemij HG, Vingerling JR, Klaver CC, van Duijn CM. A genome-wide association study of optic disc parameters. PLoS Genet 2010;6:e1000978.

60 Lim SH, St Germain E, Tran-Viet KN, Staffieri S, Marino M, Dollfus PH, Nading EB, Crowe S, Gole G, Perdomo-Trujillo Y, Haybittel M, Elder J, Pelletier V, Traboulsi E, Mackey D, Young TL. Sequencing analysis of the ATOH7 gene in individuals with optic nerve hypoplasia. Ophthalmic Genet 2014;35:1-6.

61 Garcia-Montalvo IA, Pelcastre-Luna E, Nelson-Mora J, Buentello-Volante B, Miranda-Duarte A, Zenteno JC. Mutational screening of FOXE3, GDF3, ATOH7, and ALDH1A3 in congenital ocular malformations. Possible contribution of the FOXE3 p.VAL201MET variant to the risk of severe eye malformations. Ophthalmic Genet 2014;35:190-2.

62 Wang SW, Kim BS, Ding K, Wang H, Sun D, Johnson RL, Klein WH, Gan L. Requirement for math5 in the development of retinal ganglion cells. Genes Dev 2001;15:24-9.

63 Dias J, Van Nguyen N, Georgiev P, Gaub A, Brettschneider J, Cusack S, Kadlec J, Akhtar A. Structural analysis of the KANSL1/WDR5/KANSL2 complex reveals that WDR5 is required for efficient assembly and chromatin targeting of the NSL complex. Genes Dev 2014:28:929-42.

64 Koolen DA, Kramer JM, Neveling K, Nillesen WM, Moore-Barton HL, Elmslie FV, Toutain A, Amiel J, Malan V, Tsai AC, Cheung SW, Gilissen C, Verwiel ET, Martens $S$, Feuth T, Bongers EM, de Vries P, Scheffer $H$, Vissers LE, de Brouwer AP, Brunner $H G$, Veltman JA, Schenck A, Yntema HG, de Vries BB. Mutations in the chromatin modifier gene KANSL1 cause the 17q21.31 microdeletion syndrome. Nat Genet 2012;44:639-41.

65 Zollino M, Marangi G, Ponzi E, Orteschi D, Ricciardi S, Lattante S, Murdolo M, Battaglia D, Contaldo I, Mercuri E, Stefanini MC, Caumes R, Edery P, Rossi M, Piccione M, Corsello G, Della Monica M, Scarano F, Priolo M, Gentile M, Zampino G, Vijzelaar R, Abdulrahman O, Rauch A, Oneda B, Deardorff MA, Saitta SC, Falk MJ, Dubbs H, Zackai E. Intragenic KANSL1 mutations and chromosome 17q21.31 deletions: broadening the clinical spectrum and genotype-phenotype correlations in a large cohort of patients. J Med Genet 2015;52:804-14.

66 Koolen DA, Pfundt R, Linda K, Beunders G, Veenstra-Knol HE, Conta JH, Fortuna AM, Gillessen-Kaesbach G, Dugan S, Halbach S, Abdul-Rahman OA, Winesett HM, Chung WK, Dalton M, Dimova PS, Mattina T, Prescott K, Zhang HZ, Saal HM, Hehir-Kwa JY, Willemsen MH, Ockeloen CW, Jongmans MC, Van der Aa N, Failla P, Barone C, Avola E, Brooks AS, Kant SG, Gerkes EH, Firth HV, Õunap K, Bird LM, Masser-Frye D, Friedman JR, Sokunbi MA, Dixit A, Splitt M, Kukolich MK, McGaughran J, Coe BP, Flórez J, Nadif Kasri N, Brunner HG, Thompson EM, Gecz J, Romano C, Eichler EE, de Vries BB. The Koolen-de Vries syndrome: a phenotypic comparison of patients with a 17q21.31 microdeletion versus a KANSL1 sequence variant. Eur J Hum Genet 2016;24:652-9.

67 Wright EB, Donnai D, Johnson D, Clayton-Smith J. Cutaneous features in 17q21.31 deletion syndrome: a differential diagnosis for cardio-facio-cutaneous syndrome. Clin Dysmorphol 2011:20:15-20.

68 Lone M, Kungl T, Koper A, Bottenberg W, Kammerer R, Klein M, Sweeney ST, Auburn RP, O'Kane CJ, Prokop A. The nuclear protein Waharan is required for endosomallysosomal trafficking in Drosophila. J Cell Sci 2010;123:2369-74.
69 Stevens E, Carss KJ, Cirak S, Foley AR, Torelli S, Willer T, Tambunan DE, Yau S, Brodd L, Sewry CA, Feng L, Haliloglu G, Orhan D, Dobyns WB, Enns GM, Manning M, Krause A, Salih MA, Walsh CA, Hurles M, Campbell KP, Manzini MC, Stemple D, Lin YY, Muntoni F. Mutations in B3GALNT2 cause congenital muscular dystrophy and hypoglycosylation of -dystroglycan. Am J Hum Genet 2013;92:354-65.

70 Willer T, Lee H, Lommel M, Yoshida-Moriguchi T, de Bernabe DB, Venzke D, Cirak S, Schachter H, Vajsar J, Voit T, Muntoni F, Loder AS, Dobyns WB, Winder TL, Strahl S, Mathews KD, Nelson SF, Moore SA, Campbell KP. ISPD loss-of-function mutations disrupt dystroglycan 0-mannosylation and cause Walker-Warburg syndrome. Nat Genet 2012;44:575-80.

71 Roscioli T, Kamsteeg EJ, Buysse K, Maystadt I, van Reeuwijk J, van den Elzen C, van Beusekom E, Riemersma M, Pfundt R, Vissers LE, Schraders M, Altunoglu U, Buckley MF, Brunner HG, Grisart B, Zhou H, Veltman JA, Gilissen C, Mancini GM, Delrée $P$, Willemsen MA, Ramadža DP, Chitayat D, Bennett C, Sheridan E, Peeters EA, Tan-Sindhunata GM, de Die-Smulders CE, Devriendt K, Kayserili H, El-Hashash OA, Stemple DL, Lefeber DJ, Lin YY, van Bokhoven H. Mutations in ISPD cause Walker-Warburg syndrome and defective glycosylation of -dystroglycan. Nat Genet 2012:44:581-5

72 Wright KM, Lyon KA, Leung H, Leahy DJ, Ma L, Ginty DD. Dystroglycan organizes axon guidance cue localization and axonal pathfinding. Neuron 2012;76:931-44

73 Abdollahi MR, Morrison E, Sirey T, Molnar Z, Hayward BE, Carr IM, Springell K, Woods CG, Ahmed M, Hattingh L, Corry P, Pilz DT, Stoodley N, Crow Y, Taylor GR Bonthron DT, Sheridan E. Mutation of the variant alpha-tubulin TUBA8 results in polymicrogyria with optic nerve hypoplasia. Am J Hum Genet 2009;85:737-44.

74 Braun A, Breuss M, Salzer MC, Flint J, Cowan NJ, Keays DA. Tuba8 is expressed at low levels in the developing mouse and human brain. Am J Hum Genet 2010;86:819-22.

75 Atasoy D, Schoch S, Ho A, Nadasy KA, Liu X, Zhang W, Mukherjee K, Nosyreva ED, Fernandez-Chacon R, Missler M, Kavalali ET, Südhof TC. Deletion of CASK in mice is lethal and impairs synaptic function. Proc Natl Acad Sci U S A 2007;104:2525-30.

76 Najm J, Horn D, Wimplinger I, Golden JA, Chizhikov VV, Sudi J, Christian SL, Ullmann R, Kuechler A, Haas CA, Flubacher A, Charnas LR, Uyanik G, Frank U, Klopocki E, Dobyns WB, Kutsche K. Mutations of CASK cause an X-linked brain malformation phenotype with microcephaly and hypoplasia of the brainstem and cerebellum. Nat Genet 2008:40:1065-7.

77 Moog U, Bierhals T, Brand K, Bautsch J, Biskup S, Brune T, Denecke J, de DieSmulders CE, Evers C, Hempel M, Henneke M, Yntema H, Menten B, Pietz J, Pfundt R, Schmidtke J, Steinemann D, Stumpel CT, Van Maldergem L, Kutsche K. Phenotypic and molecular insights into CASK-related disorders in males. Orphanet J Rare Dis 2015;10:44.

78 Moog U, Kutsche K, Kortüm F, Chilian B, Bierhals T, Apeshiotis N, Balg S, Chassaing $N$, Coubes C, Das S, Engels H, Van Esch H, Grasshoff U, Heise M, Isidor B, Jarvis J, Koehler U, Martin T, Oehl-Jaschkowitz B, Ortibus E, Pilz DT, Prabhakar P, Rappold G, Rau I, Rettenberger G, Schlüter G, Scott RH, Shoukier M, Wohlleber E, Zirn B, Dobyns WB, Uyanik G. Phenotypic spectrum associated with CASK loss-of-function mutations. J Med Genet 2011:48:741-51.

79 Srivastava S, McMillan R, Willis J, Clark H, Chavan V, Liang C, Zhang H, Hulver M, Mukherjee K. X-linked intellectual disability gene CASK regulates postnatal brain growth in a non-cell autonomous manner. Acta Neuropathol Commun 2016;4:30.

80 Dauber A, Golzio C, Guenot C, Jodelka FM, Kibaek M, Kjaergaard S, Leheup B, Martinet D, Nowaczyk MJ, Rosenfeld JA, Zeesman S, Zunich J, Beckmann JS, Hirschhorn JN, Hastings ML, Jacquemont S, Katsanis N. SCRIB and PUF60 are primary drivers of the multisystemic phenotypes of the $8 q 24.3$ copy-number variant. Am J Hum Genet 2013:93:798-811.

81 El Chehadeh S, Kerstjens-Frederikse WS, Thevenon J, Kuentz P, Bruel AL, ThauvinRobinet $C$, Bensignor $C$, Dollfus $H$, Laugel V, Rivière JB, Duffourd $Y$, Bonnet $C$, Robert MP, Isaiko R, Straub M, Creuzot-Garcher C, Calvas P, Chassaing N, Loeys B, Reyniers E, Vandeweyer G, Kooy F, Hancárová M, Havlovicová M, Prchalová D, Sedlácek Z, Gilissen C, Pfundt R, Wassink-Ruiter JS, Faivre L. Dominant variants in the splicing factor PUF60 cause a recognizable syndrome with intellectual disability, heart defects and short stature. Eur J Hum Genet 2016;25:43-51.

82 Armour CM, Allanson JE. Further delineation of cardio-facio-cutaneous syndrome: clinical features of 38 individuals with proven mutations. J Med Genet 2008:45:249-54

83 van Trier DC, Vos AM, Draaijer RW, van der Burgt I, Draaisma JM, Cruysberg JR Ocular manifestations of noonan syndrome: a prospective clinical and genetic study of 25 patients. Ophthalmology 2016;123:2137-46.

84 Urosevic J, Sauzeau V, Soto-Montenegro ML, Reig S, Desco M, Wright EM, Cañamero M, Mulero F, Ortega S, Bustelo XR, Barbacid M. Constitutive activation of B-Raf in the mouse germ line provides a model for human cardio-facio-cutaneous syndrome. Proc Natl Acad Sci U S A 2011;108:5015-20.

85 Andreadi C, Cheung LK, Giblett S, Patel B, Jin H, Mercer K, Kamata T, Lee P, Williams A, McMahon M, Marais R, Pritchard C. The intermediate-activity (L597V)BRAF mutant acts as an epistatic modifier of oncogenic RAS by enhancing signaling through the RAF/MEK/ERK pathway. Genes Dev 2012;26:1945-58.

86 Dupé V, Matt N, Garnier JM, Chambon P, Mark M, Ghyselinck NB. A newborn lethal defect due to inactivation of retinaldehyde dehydrogenase type 3 is prevented by maternal retinoic acid treatment. Proc Natl Acad Sci U S A 2003;100:14036-41. 
87 Fares-Taie L, Gerber S, Chassaing N, Clayton-Smith J, Hanein S, Silva E, Serey M, Serre V, Gérard X, Baumann C, Plessis G, Demeer B, Brétillon L, Bole C, Nitschke P, Munnich A, Lyonnet S, Calvas P, Kaplan J, Ragge N, Rozet JM. ALDH1A3 mutations cause recessive anophthalmia and microphthalmia. Am J Hum Genet 2013;92:265-70.

88 Yahyavi M, Abouzeid H, Gawdat G, de Preux AS, Xiao T, Bardakjian T, Schneider A, Choi A, Jorgenson E, Baier H, El Sada M, Schorderet DF, Slavotinek AM. ALDH1A3 loss of function causes bilateral anophthalmia/microphthalmia and hypoplasia of the optic nerve and optic chiasm. Hum Mol Genet 2013;22:3250-8.

89 Molotkov A, Molotkova N, Duester G. Retinoic acid guides eye morphogenetic movements via paracrine signaling but is unnecessary for retinal dorsoventral patterning. Development 2006;133:1901-10.

90 Schuurs-Hoeijmakers JH, Geraghty MT, Kamsteeg EJ, Ben-Salem S, de Bot ST, Nijhof B, van de Vondervoort Vondervoort, van der Graaf M, Nobau AC, OtteHöller I, Vermeer S, Smith AC, Humphreys P, Schwartzentruber J, Ali BR, AlYahyaee SA, Tariq S, Pramathan T, Bayoumi R, Kremer HP, van de Warrenburg $B P$, van den Akker WM, Gilissen C, Veltman JA, Janssen IM, Vulto-van Silfhout AT, van der Velde-Visser S, Lefeber DJ, Diekstra A, Erasmus CE, Willemsen MA, Vissers LE, Lammens $M$, van Bokhoven $H$, Brunner HG, Wevers RA, Schenck A, Al-Gazali L, de Vries BB, de Brouwer AP. FORGE Canada Consortium. Mutations in DDHD2, encoding an intracellular phospholipase $A(1)$, cause a recessive form of complex hereditary spastic paraplegia. Am J Hum Genet 2012;91:1073-81.
91 Inloes JM, Hsu KL, Dix MM, Viader A, Masuda K, Takei T, Wood MR, Cravatt BF. The hereditary spastic paraplegia-related enzyme DDHD2 is a principal brain triglyceride lipase. Proc Natl Acad Sci U S A 2014;111:14924-9.

92 Chow RL, Lang RA. Early eye development in vertebrates. Annu Rev Cell Dev Biol 2001;17:255-96.

93 Schwarz M, Cecconi F, Bernier G, Andrejewski N, Kammandel B, Wagner M, Gruss P. Spatial specification of mammalian eye territories by reciprocal transcriptional repression of Pax2 and Pax6. Development 2000;127:4325-34.

94 Klimova L, Kozmik Z. Stage-dependent requirement of neuroretinal Pax6 for lens and retina development. Development 2014;141:1292-302.

95 Torres M, Gómez-Pardo E, Gruss P. Pax2 contributes to inner ear patterning and optic nerve trajectory. Development 1996;122:3381-91.

96 Mui SH, Kim JW, Lemke G, Bertuzzi S. Vax genes ventralize the embryonic eye. Genes Dev 2005;19:1249-59.

97 Inoue M, Kamachi Y, Matsunami H, Imada K, Uchikawa M, Kondoh H. PAX6 and SOX2-dependent regulation of the Sox2 enhancer N-3 involved in embryonic visual system development. Genes Cells 2007;12:1049-61.

98 Kamachi Y, Uchikawa M, Tanouchi A, Sekido R, Kondoh H. Pax6 and SOX2 form a coDNA-binding partner complex that regulates initiation of lens development. Genes Dev 2001;15:1272-86.

99 Matsushima D, Heavner W, Pevny LH. Combinatorial regulation of optic cup progenitor cell fate by SOX2 and PAX6. Development 2011;138:443-54.

100 Kong L, Fry M, Al-Samarraie M, Gilbert C, Steinkuller PG. An update on progress and the changing epidemiology of causes of childhood blindness worldwide. J Aapos 2012;16:501-7. 